\title{
Driving small-scale fisheries in developing countries
}

\author{
Steven W. Purcell ${ }^{1 *}$ and Robert S. Pomeroy ${ }^{2}$ \\ ${ }^{1}$ National Marine Science Centre, Southern Cross University, Coffs Harbour, NSW, Australia, ${ }^{2}$ Agricultural and Resource \\ Economics/CT Sea Grant, University of Connecticut-Avery Point, Groton, CT, USA
}

Small-scale fisheries (SSFs) engage the vast majority of the world's fishers but are struggling to keep pace with coastal populations, and stocks are declining to levels that threaten reproductive capacity. The provision of food and livelihoods to low-income fishers into the future will be unlikely without radical changes to fisheries policy. We draw on repeating analogies of driving a car to illustrate fundamental reforms needed for driving (managing) SSFs. SSFs will continue to be unsustainable by relying too heavily on output controls (the "brake"). Managers need to move away from routinely using moratoria (i.e., the "handbrake") as a management measure, although these measures may be needed as a last resort. Scientists ("backseat drivers") must engage more

OPEN ACCESS

Edited by:

Annadel Salvio Cabanban, PRIMEXIANZDEC, Philippines

Reviewed by: Fabio Pranovi,

University of Venice, Italy

Fabian Zimmermann,

University of Bergen, Norway

*Correspondence:

Steven W. Purcell,

National Marine Science Centre, Southern Cross University, Bay Drive,

Charlesworth Bay, PO Box 4321,

Coffs Harbour 2450, Australia

steven.purcell@scu.edu.au

Specialty section:

This article was submitted to Marine Fisheries, Aquaculture and

Living Resources,

a section of the journal

Frontiers in Marine Science

Received: 17 March 2015

Accepted: 31 May 2015

Published: 19 June 2015

Citation:

Purcell SW and Pomeroy RS (2015)

Driving small-scale fisheries in developing countries.

Front. Mar. Sci. 2:44

doi: 10.3389/fmars.2015.00044 directly with fishery management agencies to understand their constraints and needs. Resource managers must come to terms with regulating fishing inputs (the "accelerator") by imposing limited-entry rules, vessel limitations, or short fishing seasons in addition to sensible output controls. Reforms to resource management will need to entail unpopular measures if SSFs are to deliver sustained benefits to fishing communities into the future.

Keywords: artisanal, coral reef, fishing effort, management measures, fishery regulations, resource, coastal, governance

\section{Introduction}

Artisanal and small-scale fisheries (SSFs) play a crucial role as a source of livelihoods, food security and income for millions of people around the world in both developed and developing countries (Allison and Ellis, 2001; Berkes et al., 2001). SSFs abound in developing countries throughout the tropics because many of the tropical marine fishes and invertebrates are in waters accessible by shallow fishing gears, breath-hold divers, and intertidal gleaners. Most of the tropical SSFs in developing countries are complex to manage, being multi-species and multi-gear (Berkes et al., 2001). They are tied inextricably to the resilience and fate of coastal and reef ecosystems (Hawkins and Roberts, 2004; Batista et al., 2014), which are simultaneously impacted by global and local stressors (Hoegh-Guldberg et al., 2007).

In spite of the important role that SSFs play in national and local economies (Mills et al., 2011), the sector-as compared against other sectors of the world food economy-is poorly planned and regulated, inadequately funded, and marginalized and often neglected by all levels of government (Smith, 1979; Kura et al., 2004; World Bank, 2004). SSFs around the globe are frequently overfished and overexploited as a result of not only weak governance, but, to name just a few issues, of poor management, perverse subsidies, corruption, unrestricted access, and destructive fishing practices (CRS, 2006).

If managed more effectively, SSFs can contribute strongly to reducing poverty and improving food security in developing countries in the long-term. Better management can also avoid 
the continuing collapse of aquatic and marine ecosystems and the loss of associated biodiversity occurring throughout the world's oceans and aquatic environments (Berkes et al., 2001).

The solutions can be hard fought and complex (McClanahan et al., 2009; Pomeroy, 2012). However, the underlying tenets of why management is failing and what elements of the system are most in need of reform can be better understood when unpacked in familiar terms. Here, we use an analogy of driving a car to illustrate the fundamental problems and solutions for ailing SSFs in developing and low-income countries.

\section{Driving Small Scale Fisheries}

SSFs operate from shore or with small vessels (Allison and Ellis, 2001), and (especially regarding artisanal types) involve simple fishing gears with low capital investment (FAO, 2014). Compared to industrial fisheries, research on small-scale and artisanal fisheries lagged until the past decade (Figure 1). The recent exponential explosion in research on SSFs may be explained by the realizations that artisanal fishing can profoundly affect fish and invertebrate stocks globally (Batista et al., 2014) and that they play a crucial role in poverty reduction and food security (Allison and Ellis, 2001). Until the 1980s, research on SSFs mainly concerned biological aspects, but inroads were made on understanding fishers and fishing communities (Pomeroy, 2015). Research in the 1980s highlighted the importance of a multidisciplinary approach to research and management, and literature in the 1990s expanded through a rise in socioeconomic studies. Governance of SSFs became a major area of research since 2000 and further literature expanded through a number of new approaches to SSFs (see Pomeroy, 2015).

Over the past decades, total catches and catch-per-uniteffort of fishing have declined dramatically in many artisanal fisheries throughout the tropics (Sadovy, 2005; Zeller et al.,

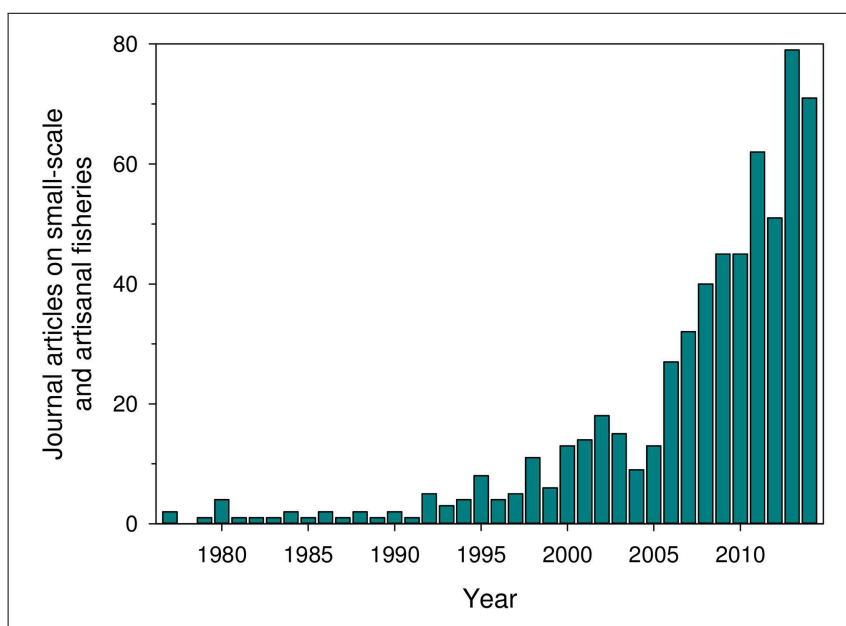

FIGURE 1 | Publication of scientific journal articles on small-scale and artisanal fisheries from 1977 to $\mathbf{2 0 1 4}$. Data are from a search in SCOPUS for publications with small-scale, or artisanal, and fisher* (fisher, fishery, fisheries) in the article title. Clearly, this does not include all articles about small-scale fisheries, as some titles may not have these words.
2007, 2014; Bender et al., 2014; Muallil et al., 2014). Following concern for overexploitation and environmental degradation and poor outcomes of management (CRS, 2006), many institutions have been improving the objectives and policies for SSFs. The objectives have shifted from maximizing annual catches and employment, sustaining stocks, and short-term interests, to a broader framework for management of marine resources to achieve sustainable development through improved ecological and human well-being. Subsequently, there has been a shift in the types of fisheries management measures used to achieve these objectives. This constitutes a shift in the brakes, the handbrake, the accelerator, the steering wheel, and the driver.

A range of forces are compounding the already complex challenges facing SSFs, namely weak governance, socioeconomic conditions, local organization, and ecosystem change. Weak governance is a key underlying cause of overfishing, characterized by corruption, poor stakeholder participation, poor enforcement, weak institutional capacity, overcapacity of fishing fleets, and illegal fishing. Legal, policy, and institutional frameworks are often not crafted to suit the unique features of fisheries and this has resulted in mismatches and overlaps (Torell and Salamanca, 2002)-within nations there are ministries with opposite goals for instance. Governance reforms in recent decades have focussed on administrative decentralization, i.e., dispersal of power, authority, and responsibility from the central government to lower or local-level institutions (Pomeroy, 2001, 2003; Cinner et al., 2012a). This shift has effectively put the steering wheel more into the hands of local institutions and fishers.

\section{The Steering Wheel}

Governance is a lot about who is steering the management of the fishery. Unlike driving a car, a single organization's control of managing the fishery has tended to be unsuccessful. Many SSFs have remained managed by top-down (government-controlled) systems with little or no participation of fisher groups (e.g., Purcell et al., 2014; Eriksson et al., 2015a).

At the other extreme, too many hands on the wheel has also been problematic because fishery governance needs good leadership (Pomeroy et al., 2001; Gutiérrez et al., 2011). This is evident in places like Zanzibar, where multiple government and non-government organizations participate in the management of SSFs yet stocks are severely overfished (Eriksson et al., 2015b).

Experience has shown that co-management over the decisionmaking and strategy of SSF management is beneficial (Castilla and Fernandez, 1998; Cinner et al., 2012b), although does not guarantee a successful fishery (Eriksson et al., 2015a). A comanaged structure allows for an empowered and organized group of stakeholders to jointly develop a plan with clear objectives on how to "steer" the fishery. In this regard, improvements can be made simply by formalizing pre-agreed objectives of the fishery and reference limits defining the bounds of unsatisfactory management performance (FAO, 2003). Better steering of the SSFs will come from stronger engagement with fishers and new pathways for them to feedback ideas and concerns to fishery managers and academics. 


\section{The Brake}

Output controls can be seen as the "brake" in SSF management, because they can slow down the rate of fishing mortality. Although there are exceptions (e.g., Salas et al., 2007), managers of SSFs in many developing countries have relied too much on output controls (e.g., size limits, catch quotas) compared to important input controls such as limited-entry rules, seasonal closures, and vessel limits (Dalzell and Adams, 1997; Purcell et al., 2014). For example, of the Pacific Island sea cucumber fisheries, $30 \%$ have quotas and size limits (output controls) but none have capacity controls on boats and only one has limited entry regulations (input controls) (Purcell et al., 2013, Supplemental Data). In as much as a car's speed should not be controlled predominantly by the brake, fisheries should not be managed primarily by output controls.

Size limits have been a cornerstone of classic fisheries management, since they logically protect immature animals and minimize growth overfishing (Pikitch et al., 2004; Purcell, 2010). However, large individuals contribute the most to reproduction and recent debate holds that selectivity for large individuals may result in ecological and evolutionary side effects to populations (Garcia et al., 2012; Laugen et al., 2014). The ensuing conclusion is for "balanced" harvests across a wider spectrum of the stock with consideration of ecosystem structure and productivity (Garcia et al., 2012). Mono-specific fisheries, such as those for Trochus niloticus, will probably benefit from size selectivity imposed on fishers. On the other hand, size limits are complicated in multi-species fisheries, which predominate SSFs in developing countries (Salas et al., 2007). The legal sizes need to be species- or group-specific (Purcell, 2010), which can be confusing for fishers. Further, enforcement requires physical inspection of harvested animals, which takes time and presence. An alternative is to set institutional constraints and provide incentives for fishers to voluntarily introduce size selectivity, since markets may preferentially value medium or large individuals (Reddy et al., 2013; Purcell, 2014). Such approaches require engagement with communities to help fishers understand the rationale for size selectivity and support them in imposing size limits sensibly.

Catch quotas have as many failings as advantages in SSFs. This regulatory measure shines in monospecific industrial fisheries with large boats and relatively few fishers (Grafton, 1996), or in very small fishery units (Léopold et al., 2013). However, catch quotas struggle to be effective and enforceable in SSFs and management agencies lack technical capacity to implement them effectively (Copes, 1986; WHAT, 2000; Salas et al., 2007; Pomeroy, 2012; Purcell et al., 2013, 2014). Consequently, they may be inequitable and exceeded without penalty. Thus, catch quotas will be unmanageable in many SSFs.

\section{The Handbrake}

The "handbrake" in SSF management corresponds to a longterm ban, or "moratorium," in the fishery as a measure to halt fishing. Such a drastic measure is needed when the fishery is veering seriously off-track or exploitation has been too fast to adapt management measures. A moratorium can be considered a pseudo-management measure, since its effect is to stop the fishery, rather than manage exploitation. Bans, or even long (>1 y) periodic closures, disrupt livelihoods, supply chains, and post-harvest processing skills and infrastructure, which may have taken years to develop. Denying access to national resources does not go down too well with traditional users, and may precipitate unrest or violence (Shepherd et al., 2004; Salayo et al., 2008). Therefore, in as much as a handbrake should only be used in an emergency to stop a speeding car, fishing bans should be used as a last resort and certainly not a regular practice for managing fisheries.

Fishery bans may last 5 to 10 years to allow the stocks to recover, but some resources may require much more time for breeding populations to be rebuilt. Sometimes bans are lifted too early, before stocks have had much time to mature and become dense again (Skewes et al., 2010). Most importantly, if a ban has been imposed due to overfishing then the management system must be substantially changed before the ban is lifted to resume fishing.

\section{The Accelerator}

The accelerator of SSFs is the set of elements that act to speed up exploitation. In SSFs in developing countries, the main force is open access which allows too many fishers to operate in the fishery, often resulting in over-capacity (Pomeroy, 2011). This pace of exploitation is strongly influenced by the resource users (i.e., fishers) yet also tempered by managers via input controls. By and large, the problem facing SSFs is that the pace of exploitation by fishers is too fast, often because of the sheer number of fishers, and exploitation rates are not regulated enough by input controls (Dalzell and Adams, 1997; Sugiyama et al., 2004; Sadovy, 2005). Analyses from different fisheries illustrate that returns to fishers and sustainability of stocks decline sharply as participation rates in the fishery increase (Jennings and Polunin, 1996; Sadovy, 2005; Purcell et al., 2013). Over-capitalisation of fisheries with larger boats and fleets greatly compounds this problem (Pomeroy, 2011).

Difficult decisions will need to be made about the use and impacts of fishing rights and access control measures as there will be positive and negative social and economic implications. Preferential access rights can be assigned to coastal areas for small-scale fishers through group fishing rights and territorial use rights (TURFs). Some SSFs will be well suited to community property rights systems (Castilla et al., 2007). Group fishing rights and TURFs require the group's understanding of the value of the rights, the capability to co-manage the resource, the need to restrict group membership, and the ability to limit access. However, in some SSFs, the cultural or social context does not allow managers to impose limited-entry rules to trim the number of fishers (Salayo et al., 2008; Pomeroy, 2012; Carbonetti et al., 2014; Purcell et al., 2014). Fishers denied access to traditionally fished resources may also struggle economically. Fortunately, restricting who can have access to the resource is not the only input control at hand. 
More focus is needed on the control of fishing effort (Dalzell and Adams, 1997; Sadovy, 2005; Pomeroy, 2012; Purcell et al., 2014). This means using other input controls, such as limits on boat size and fishing seasons, to restrain fishing within sustainable limits. Restricting boat size can prevent fisheries evolving to semi-industrial modes, where teams of fishers are able to access distant fishing grounds and must fish more intensely to cover larger capital costs (Purcell, 2010). Vessel restrictions would benefit many SSFs but will be difficult to implement in certain fisheries (Pomeroy, 2012).

Seasonal closures are applied in many places and limit the amount of days in a year that fishers have to harvest the resource (Salas et al., 2007; Purcell et al., 2014). However, seasonal closures are often based upon reproductive seasons, rather than effort limitation, and closure periods are often too short to meaningfully reduce annual fishing effort. Very short fishing seasons (e.g., a few days or weeks p.a.) have been set in a few rare cases-and been highly successful (e.g., Bertram, 1995; McClanahan, 2011; Léopold et al., 2013). Good fishery performance rests in both the fact that annual fishing effort can be modified over time to match the turnover rates of the stock, and catch monitoring becomes affordable over short periods. Short fishing seasons are appropriate for export commodities like beche-de-mer and trochus shell but less so for when the resource is for food security (e.g., reef fish) or needed on a regular basis to maintain export supply chains (e.g., aquarium fish, live reef fish food).

Whether managers choose to regulate fishing effort or capacity by limited-entry rules, vessel capacity, or fishing duration, or a combination of these, is not so crucial. The important point is that fishing effort must be eased by one means or another to achieve sustainability - that is, measures imposed to ease off the accelerator. This will take hard decisions that will be socially unpopular. However, inaction will surely have greater ecological and social consequences in the longer-term.

\section{The Backseat Driver}

An emerging problem in fisheries is that much of the paradigms about management are made by academics and scientists in international non-governmental organizations (NGOs) with no professional work experience with managing fisheries and some are unaware of the realities that SSF managers face in low-income countries. This means that management advice from scientists or NGOs takes scientists' or NGOs' perspectives. In effect, scientists and NGOs become the "backseat driver": the person voicing directions to the driver (the fishery manager) from a distance.

Management measures advocated by [us] scientists and NGOs are biased toward certain measures. In particular, marine reserves have become the poster-child for marine conservation and management. This focus stems to a fair extent from the fact that marine reserve (marine protected area [MPA] or no-take zone [NTZ]) research is logically feasible and of intellectual interest (McClanahan, 2011). The scientific literature is flooded with articles about marine reserves (McClanahan, 2011), many recommending them as a main solution to fisheries management (Johnson et al., 2013). Consequently, many NGOs push for the use of MPAs in developing countries, and it is no coincidence that human resources in fishery management agencies are disproportionately weighted on planning and implementing MPAs at the expense of other management tasks (Purcell et al., 2014). While well enforced no-take reserves are superb for conservation, they may or may not have a big impact on sustainability of stocks in fishing grounds, especially where enforcement is weak (McClanahan et al., 2006; Purcell et al., 2013). Our point is that over-weighting of advice from scientists on certain management measures may indeed lead to imbalanced management and the neglect of regulatory measures and management actions that may be more important for fishery sustainability.

\section{Conclusions}

Improving SSFs should involve closer and more practical links (e.g., work placements) between scientists/NGOs and fishery managers, better balance of input and output control measures to reduce fishing pressure, and better information exchange among fishers, fishery managers, and scientists/NGOs (Figure 2). Management in SSFs has often relied too heavily on output controls (the brake) without addressing the exploitation pressures (the accelerator). Input controls may also fail if not used in combination with other regulatory measures, so the key is to impose a balanced set of both input and output controls. In lowincome countries, development is the key issue, so there tends to be a focus on exploitation by the government, and conservation by NGOs. In many cases, exploitation has sped out of control, forcing managers to place moratoria (the handbrake) on fishing. Just as a car cannot be driven with the accelerator constantly depressed, a fishery cannot be managed sustainably with fishing effort at continuous full pace. SSF managers need to either greatly restrict the number of fishers, or boat size or days per year that fishers can exploit the resource. We realize the dilemma here that fisheries are important for the welfare, livelihoods and economic security of the poor (Béné et al., 2010) yet the glaring solution is to restrict effort. Failing to rein in fishing capacity and/or effort in small scale fisheries will continue to result in overfishing and loss of future livelihoods, biodiversity and ecosystem functions of exploited species. The solutions need to be culturally and context specific, and integrated socially through forums with fishers (McClanahan et al., 2009).

Difficult decisions will need to be made about the use and impacts of fishing rights and access control measures as there will be positive and negative social and economic implications. Implementation of any control measure must be simple and cost-effective due to limited resources for administration and enforcement. Livelihoods must be considered to be an equal and complementary approach to fisheries management measures (Allison and Ellis, 2001). We must make fisheries managers, fishers and development agencies more aware of the range of fisheries management measures available to them. The corollary is that scientists and NGOs (the backseat drivers) need to turn their focus to researching a wider range of management measures (McClanahan, 2011; Johnson et al., 2013). Scientists and research students will need to engage more 


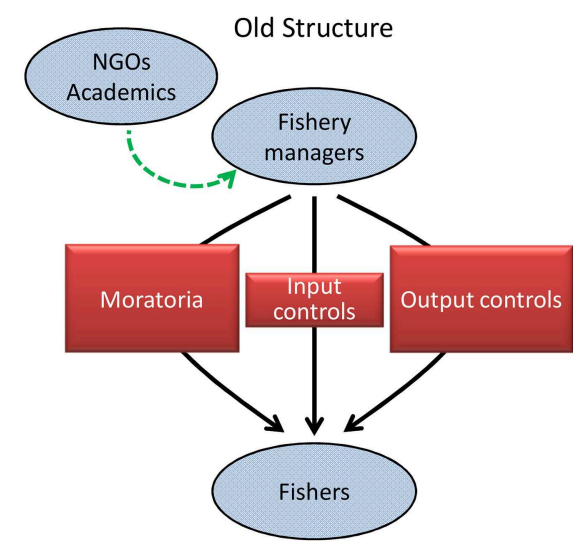

FIGURE 2 | Old and improved structures for information exchange and regulatory controls in small-scale fisheries. Solid lines denote the development and imposition of regulatory controls; dotted lines denote communication pathways. The improved structure sees exchange of

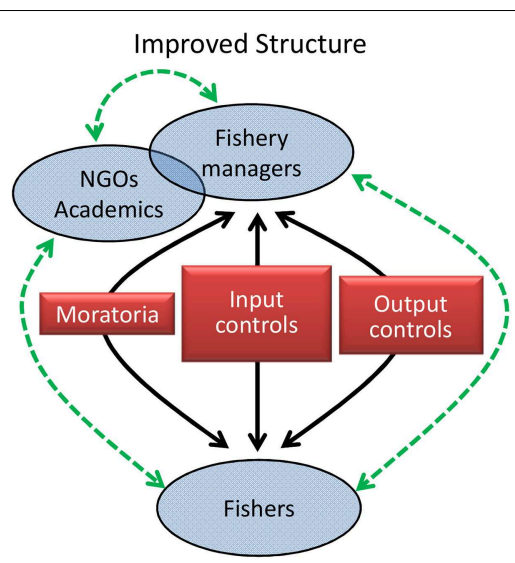

information among NGOs/academics and fishery managers and fishers, inputs from fishers to the development of regulatory measures, closer physical collaborations between NGOs/academics and fishery managers, and a better balance of input and output control measures. actively with fishery managers and fishers to become part of the solution.

Governance must also be strengthened in SSFs in developing countries, especially through unwavering political will on the part of political and judicial leaders and bureaucrats (Carbonetti et al., 2014). Inaction of political and judicial leaders in enforcing laws and regulations may be due to alleged or real corruption or due to the real or perceived negative impacts of fisheries management decisions on fishers' livelihoods, incomes and food security. Several potential ideal-type pathways for overcoming hurdles to lack of political will and capacity exist, including the importance of leadership on fisheries governance at both the local and national level (Pomeroy et al., 2001; Gutiérrez et al., 2011), and the education of the public to generate the values necessary to ensure cooperation and enforcement of fisheries management policies.

The only effective solution will be one based on a coordinated and integrated approach involving resource

\section{References}

Allison, E. H., and Ellis, F. (2001). The livelihoods approach and management of small-scale fisheries. Mar. Policy 25, 377-388. doi: 10.1016/S0308597X(01)00023-9

Batista, V. S., Fabré, N. N., Malhado, A. C. M., and Ladle, R. J. (2014). Tropical artisanal coastal fisheries: challenges and future directions. Rev. Fish. Sci. Aquaculture 22, 1-15. doi: 10.1080/10641262.2013.822463

Béné, C., Hersoug, B., and Allison, E. H. (2010). Not by rent alone: analysing the pro-poor functions of small-scale fisheries in developing countries. Dev. Policy Rev. 28, 325-358. doi: 10.1111/j.1467-7679.2010.00486.x

Bender, M. G., Machado, G. R., De Azevedo Silva, P. J., Floeter, S. R., MonteiroNetto, C., Luiz, O. J., et al. (2014). Local ecological knowledge and scientific data reveal overexploitation by multigear artisanal fisheries in the Southwestern Atlantic. PLoS ONE 9:e110332. doi: 10.1371/journal.pone.0110332

Berkes, F., Mahon, R., McConney, P., Pollnac, R., and Pomeroy, R. (2001). Managing Small-scale Fisheries: Alternative Directions and Methods. Ottawa, ON: International Development Research Centre. management, resource restoration and conservation, livelihood, economic, and community development, and restructured governance arrangements (Pomeroy, 2013). This implies an increased focus on human solutions involving participation, livelihoods, rights, and communities (Allison and Ellis, 2001). The foundation of such an approach should be a plan that has been developed and agreed upon through a participatory process (see Figure 2), and which identifies goals and objectives, management and development strategies and actions, and the roles and responsibilities of all partners.

\section{Acknowledgments}

We thank the two reviewers for their constructive comments on the manuscript. SWP was supported through project funding from the Australian Centre for International Agricultural Research (ACIAR).

Bertram, I. (1995). The Aitutaki experience in the development of management strategies for the trochus fishery. SPC Trochus Inf. Bull. 4, 42-47.

Carbonetti, B., Pomeroy, R., and Richards, D. L. (2014). Overcoming the lack of political will in small scale fisheries. Mar. Policy 44, 295-301. doi: 10.1016/j.marpol.2013.09.020

Castilla, J. C., and Fernandez, M. (1998). Small-scale benthic fisheries in Chile: on co-management and sustainable use of benthic invertebrates. Ecol. Appl. 8, S124-S132. doi: 10.1890/1051-0761(1998)8[S124:SBFICO]2.0.CO;2

Castilla, J. C., Gelcich, S., and Defeo, O. (2007). "Successes, lessons, and projections from experience in marine benthic invertebrate artisanal fisheries in Chile," in Fisheries Management: Progress Towards Sustainability, eds T. R. McClanahan and J. C. Castilla (Oxford: Blackwell Publishing Ltd.), 23-42.

Cinner, J. E., Daw, T. M., McClanahan, T. R., Muthiga, N., Abunge, C., Hamed, S., et al. (2012a). Transitions toward co-management: the process of marine resource management devolution in three east African countries. Glob. Environ. Change 22, 651-658. doi: 10.1016/j.gloenvcha.2012.03.002

Cinner, J. E., McClanahan, T. R., MacNeil, M. A., Graham, N. A. J., Daw, T. M., Mukminin, A., et al. (2012b). Comanagement of coral reef 
social-ecological systems. Proc. Natl. Acad. Sci. U.S.A. 109, 5219-5222. doi: 10.1073/pnas.1121215109

Copes, P. (1986). A critical review of the individual quota as a device in fisheries management. Land Econ. 62, 278-291. doi: 10.2307/3146392

CRS (2006). Fisheries Opportunities Assessment. University of Rhode Island and Florida International University.

Dalzell, P., and Adams, T. J. H. (1997). Sustainability and management of reef fisheries in the Pacific Islands. Proc. 8th Int. Coral Reef Sym. 2, 2027-2032.

Eriksson, H., Conand, C., Lovatelli, A., Muthiga, N. A., and Purcell, S. W. (2015a). Governance structures and sustainability in Indian Ocean sea cucumber fisheries. Mar. Policy 56, 16-22. doi: 10.1016/j.marpol.2015.02.005

Eriksson, H., de la Torre-Castro, M., Purcell, S. W., and Olsson, P. (2015b). Lessons for resource conservation from two contrasting small-scale fisheries. Ambio 44, 204-213. doi: 10.1007/s13280-014-0552-5

FAO (2003). Fisheries Management. 2. The Ecosystem Approach to Fisheries. Rome: FAO.

FAO (2014). Small-Scale and Artisanal Fisheries [Online]. Rome: FAO. Available online at: http://www.fao.org/fishery/topic/14753/en (Accessed 2014).

Garcia, S. M., Kolding, J., Rice, J., Rochet, M. J., Zhou, S., Arimoto, T., et al. (2012). Reconsidering the consequences of selective fisheries. Science 335, 1045-1047. doi: $10.1126 /$ science. 1214594

Grafton, R. Q. (1996). Individual transferable quotas: theory and practice. Rev. Fish Biol. Fish 6, 5-20. doi: 10.1007/BF00058517

Gutiérrez, N. L., Hilborn, R., and Defeo, O. (2011). Leadership, social capital and incentives promote successful fisheries. Nature 470, 386-389. doi: 10.1038 /nature09689

Hawkins, J. P., and Roberts, C. M. (2004). Effects of artisanal fishing on Caribbean coral reefs. Conserv. Biol. 18, 215-226. doi: 10.1111/j.1523-1739.2004.00328.x

Hoegh-Guldberg, O., Mumby, P. J., Hooten, A. J., Steneck, R. S., Greenfield, P., Gomez, E., et al. (2007). Coral reefs under rapid climate change and ocean acidification. Science 318, 1737-1742. doi: 10.1126/science.1152509

Jennings, S., and Polunin, N. V. C. (1996). Effects of fishing effort and catch rate upon the structure and biomass of Fijian reef fish communities. J. Appl. Ecol. 33, 400-412. doi: 10.2307/2404761

Johnson, A. E., Cinner, J. E., Hardt, M. J., Jacquet, J., McClanahan, T. R., and Sanchirico, J. N. (2013). Trends, current understanding and future research priorities for artisanal coral reef fisheries research. Fish Fish. 14, 281-292. doi: 10.1111/j.1467-2979.2012.00468.x

Kura, Y., Revenga, C., Hoshino, E., and Mock, G. (2004). Fishing for Answers: Making Sense of the Global Fish Crisis. Washington, DC: World Resource Institute.

Laugen, A. T., Engelhard, G. H., Whitlock, R., Arlinghaus, R., Dankel, D. J., Dunlop, E. S., et al. (2014). Evolutionary impact assessment: accounting for evolutionary consequences of fishing in an ecosystem approach to fisheries management. Fish Fish. 15, 65-96. doi: 10.1111/faf.12007

Léopold, M., Cornuet, N., Andréfouet, S., Moenteapo, Z., Duvauchelle, C., Raubani, J., et al. (2013). Comanaging small-scale sea cucumber fisheries in New Caledonia and Vanuatu using stock biomass estimates to set spatial catch quotas. Environ. Conserv. 40, 367-379. doi: 10.1017/S0376892913 00009X

McClanahan, T. R. (2011). Human and coral reef use interactions: from impacts to solutions? J. Exp. Mar. Biol. Ecol. 408, 3-10. doi: 10.1016/j.jembe.2011.07.021

McClanahan, T. R., Castilla, J. C., White, A. T., and Defeo, O. (2009). Healing small-scale fisheries by facilitating complex socio-ecological systems. Rev. Fish Biol. Fish 19, 33-47. doi: 10.1007/s11160-008-9088-8

McClanahan, T. R., Marnane, M. J., Cinner, J. E., and Kiene, W. E. (2006). A comparison of marine protected areas and alternative approaches to coral-reef management. Curr. Biol. 16, 1408-1413. doi: 10.1016/j.cub.2006.05.062

Mills, D. J., Westlund, L., De Graaf, G., Kura, Y., Willman, R., and Kelleher, K. (2011). "Under-reported and undervalued: small-scale fisheries in the developing world," in Small-Scale Fisheries Management: Frameworks and Approaches for the Developing World, eds R. S. Pomeroy and N. L. Andrew (Wallingford; Oxfordshire: CABI International), 1-15. doi: 10.1079/9781845936075.0001

Muallil, R. N., Mamauag, S. S., Cababaro, J. T., Arceo, H. O., and Aliño, P. M. (2014). Catch trends in Philippine small-scale fisheries over the last five decades: the fishers perspectives. Mar. Policy 47, 110-117. doi: 10.1016/j.marpol.2014.02.008
Pikitch, E. K., Santora, C., Babcock, E. A., Bakun, A., Bonfil, R., Conover, D. O., et al. (2004). Ecosystem-based fishery management. Science 305, 346-347. doi: $10.1126 /$ science. 1098222

Pomeroy, R. S. (2001). "Devolution and fisheries co-management," in Collective Action, Property Rights and Devolution of Natural Resource Management Exchange of Knowledge and Implications for Policy, eds R. Meinzen-Dick, A. Knox, and M. Di Gregorio (Feldafing: Zentralstelle fur Ernahrung und Landwirtschaft), 111-146.

Pomeroy, R. S. (2003). "The government as a partner in co-management," in The Fisheries Co-management Experience: Accomplishments, Challenges and Prospects, eds D. G. Wilson, J. Raakjaer-Nielsen, and P. Degnbol (Dordrecht: Kluwer Academic Publishers), 247-261.

Pomeroy, R. S. (2011). "Managing overcapacity in small-scale fisheries," in Small-Scale Fisheries Management: Frameworks and Approaches for the Developing World, eds R. S. Pomeroy and N. L. Andrew (Wallingford, Oxfordshire: $\mathrm{CAB}$ International), 75-92. doi: 10.1079/97818459360 75.0075

Pomeroy, R. S. (2012). Managing overcapacity in small-scale fisheries in Southeast Asia. Mar. Policy 36, 520-527. doi: 10.1016/j.marpol.2011. 10.002

Pomeroy, R. S. (2013). "Marine Fisheries in Crisis: improving Fisheries Management in Southeast Asia," in New Security Challenges in Asia, eds R. Hathaway and M. Mills (Washingon, DC: Woodrow Wilson Center Press), 99-120.

Pomeroy, R. S. (2015). "Linking science and people: applying socioeconomic and governance science to solve problems and create opportunities in Caribbean fisheries," in Proceedings of the 67th Gulf and Caribbean Fisheries Institute Conference (Barbados)

Pomeroy, R. S., Katon, B. M., and Harkes, I. (2001). Conditions affecting the success of fisheries co-management: lessons from Asia. Mar. Policy 25, 197-208. doi: 10.1016/S0308-597X(01)00010-0

Purcell, S. W. (2010). Managing Sea Cucumber Fisheries with an Ecosystem Approach, FAO Fisheries and Aquaculture Technical Paper No. 520. Rome: FAO.

Purcell, S. W. (2014). Value, market preferences and trade of bechede-mer from Pacific Island sea cucumbers. PLoS ONE 9:e95075. doi 10.1371/journal.pone.0095075

Purcell, S. W., Lovatelli, A., and Pakoa, K. (2014). Constraints and solutions for managing Pacific Island sea cucumber fisheries with an ecosystem approach. Mar. Policy 45, 240-250. doi: 10.1016/j.marpol.2013.11.005

Purcell, S. W., Mercier, A., Conand, C., Hamel, J. F., Toral-Granda, M. V., Lovatelli, A., et al. (2013). Sea cucumber fisheries: global analysis of stocks, management measures and drivers of overfishing. Fish Fish. 14, 34-59. doi: 10.1111/j.1467-2979.2011.00443.x

Reddy, S. M. W., Wentz, A., Aburto-Oropeza, O., Maxey, M., Nagavarapu, S., and Leslie, H. M. (2013). Evidence of market-driven size-selective fishing and the mediating effects of biological and institutional factors. Ecol. Appl. 23, 726-741. doi: 10.1890/12-1196.1

Sadovy, Y. (2005). Trouble on the reef: the imperative for managing vulnerable and valuable fisheries. Fish. Fish. 6, 167-185. doi: 10.1111/j.1467-2979.2005. 00186.x

Salas, S., Chuenpagdee, R., Seijo, J. C., and Charles, A. (2007). Challenges in the assessment and management of small-scale fisheries in Latin America and the Caribbean. Fish. Res. 87, 5-16. doi: 10.1016/j.fishres.2007.06.015

Salayo, N., Garces, L., Pido, M., Viswanathan, K., Pomeroy, R., Ahmed, M., et al. (2008). Managing excess capacity in small-scale fisheries: perspectives from stakeholders in three Southeast Asian countries. Mar. Policy 32, 692-700. doi: 10.1016/j.marpol.2007.12.001

Shepherd, S. A., Martinez, P., Toral-Granda, M. V., and Edgar, G. J. (2004). The Galapagos sea cucumber fishery: management improves as stocks decline. Environ. Conserv. 31, 102-110. doi: 10.1017/S0376892903001188

Skewes, T. D., Murphy, N. E., McLeod, I., Dovers, E., Burridge, C., and Rochester, W. (2010). Torres Strait Hand Collectables, 2009 Survey: Sea Cucumber. Cleveland, QLD: CSIRO.

Smith, I. R. (1979). A Research Framework for Traditional Fisheries. ICLARM Studies and Reviews No. 2. Manila: ICLARM.

Sugiyama, S., Staples, D., and Funge-Smith, S. J. (2004). Status and Potential of Fisheries and Aquaculture in Asia and the Pacific. Bangkok: Food and 
Agriculture Organization Regional Office for Asia and the Pacific, Publication $2004 / 25$.

Torell, M., and Salamanca, A. M. (2002). Institutional Issues and Perspectives in the Management of Fisheries and Coastal Resources in Southeast Asia. Penang: ICLARM.

WHAT (2000). Governance for a Sustainable Future: Fishing for the Future, Report of the Commission on fisheries, World Humanity Action Trust, London.

World Bank (2004). Saving Fish and Fishers, toward Sustainable and Equitable Governance of the Global Fishing Sector, Report No. 29090-GLB, Washington, D.C.

Zeller, D., Booth, S., Davis, G., and Pauly, D. (2007). Re-estimation of small-scale fishery catches for U.S. flag-associated island areas in the western Pacific: the last 50 years. Fish. Bull. 105, 266-277.
Zeller, D., Harper, S., Zylich, K., and Pauly, D. (2014). Synthesis of underreported small-scale fisheries catch in Pacific island waters. Coral Reefs 34, 25-39. doi: 10.1007/s00338-014-1219-1

Conflict of Interest Statement: The authors declare that the research was conducted in the absence of any commercial or financial relationships that could be construed as a potential conflict of interest.

Copyright () 2015 Purcell and Pomeroy. This is an open-access article distributed under the terms of the Creative Commons Attribution License (CC BY). The use, distribution or reproduction in other forums is permitted, provided the original author(s) or licensor are credited and that the original publication in this journal is cited, in accordance with accepted academic practice. No use, distribution or reproduction is permitted which does not comply with these terms. 